\title{
Vincenta de Paula žēlsirdīgo māsu apvienības darbība Latvijā
}

Priestera Vincenta de Paula (Vincent de Paul) žēlsirdīgo māsu apvienība tika nodibināta Francijā 1633. gada 29. novembrī ar mērķi palīdzēt nabagiem un slimiem cilvēkiem, kā arī audzināt un izglītot bērnus kristietības garā. Lai īstenotu labdarību, žēlsirdīgām māsām bija nepieciešama garīgā audzināšana. Šim nolūkam tika izstrādāti māsu darbības un uzvedības noteikumi (Regula), kuri bija stingri jāievēro. Žēlsirdīgo māsu darbs tika balstīts uz līdzjūtību un labsirdību un izpelnījās sabiedrības vispārēju atbalstu un cieņu. Kustība ieguva popularitāti un atzinību ne tikai Francijāa, bet arī citās valstīs, tostarp arī Latvijā (Krāslavā). Latgalē Vincenta de Paula žēlsirdīgās māsas veica savu misiju 75 gadus (1789-1864). Žēlsirdīgajām māsām, neatkarīgi no valsts, kurā tās darbojās, bija jāievēro Regula (uzvedības un darbības noteikumi), kura tika pārtulkota vairākās valodās.

Priesteris Vincents de Paula (1581-1660) piedzima Francijā, trūcīgā ǵimenē. Savā garīdznieka dzīvē viņš sastapās ar cilvēku galēju nabadzību gan garīgajā, gan materiālajā ziņā. Viņš rūpējās, lai tiktu apmierinātas trūcīgo cilvēku materiālās vajadzības. Priesterim noderēja 1617. gadā iegūtā pieredze, kalpojot Šatiljo Dombes (Chátillon les Dombres) draudzē. ${ }^{1}$ Viena draudzes locekle vērsās pie priestera ar lūgumu palīdzēt kādai

1 Sienczak B. Zgromadzenie Sióstr Miłosierdzia św. Wincentego a Paulo w Polsce (1652-2002), II Prowincja krakowska i litewska. - Kraków: Instytut Wydawniczy Księžy Misjonarzy “Nasza Przeszłośc”, 2002. - 10, 13-16 s. 
trūcīgai ǵimenei. Vincents de Paula ierosināja, lai draudzes locekļi paņem šo ǵimeni pastāvīgā aizgādībā. Šim gadījumam sekoja citi, un 1617. gadā izveidojās sieviešu žēlsirdības pulciņš. ${ }^{2}$ Izmantojot šo pieredzi, Francijā radās brālība, kas kḷuva par pamatu visai “žēlsirdības armijai”: Parīzē tika organizētas žēlsirdīgo kundžu un jaunavu apvienības. Organizācija pulcēja kopā aristokrātijas pārstāves, kuras bija materiāli nodrošinātas, bet nevarēja vai negribēja veltīt savu laiku pal̄̄dzēšanai trūcīgiem cilvēkiem. Bieži vien kundzes sūtīja savas kalpones veikt "kalpošanas darbus", kurus negribēja strādāt pašas. ${ }^{3}$

Katru svētdienu š̄is sievietes pulcējās Parīzē, svētā Lācara baznīcas apkārtnē, kur vin̄ām mācīja veikt žēlsirdības darba pienākumus. Sievietes dēvēja sevi to draudžu vārdā, no kurām bija ieradušās, piemēram, Margarita no svētā Pāvela, Marija no svētā Laurentija. ${ }^{4}$ Priesteris Vincents de Paula jaunavas dēvēja par “žēlsirdīgām māsām”. Pēc laika radās nepieciešamība māsas virzīt garīgās audzināšanas, kā arī nabago un slimo kopšanas uzdevumam. Ar šādu nolūku 1633. gada 29. novembrī jaunavas tika izmitinātas svētās Ludvikas mājā Parīzē. ${ }^{5}$ Šis datums tiek uzskatīts par žēlsirdīgo māsu apvienības dibināšanas brīdi, kad Vincents de Paula kopā ar savu atbalstītāju mūķeni Luīzi de Marilaku (Louise de Marillac, 1591-1660) Parīzē oficiāli nodibināja Žēlsirdīgo māsu apvienību, kas palīdzēja nabagiem. ${ }^{6}$ Tomēr māsu darbs ne vienmēr atbilda žēlsirdībai atbilstīgajām augstajām prasībām, jo savus pienākumus viņas veica kā parastu un pierastu darbu. ${ }^{7}$ Tādēl svētā Luīze 1634. gadā uzrakstīja žēlsirdīgo māsu darba un uzvedības

2 Halat M. Obowiązki Sióstr Miłoserdzia w świetle dokumentów, Medycyna Nowožytna / Polska akademia nauk, Instytut historii nauki, Studija nad kulturą medyczną, Tom 6 - Zeszyt 2. - Warszawa, 1999. - 153 s.

3 Sienczak B. Zgromadzenie Sióstr Miłosierdzia św. Wincentego a Paulo w Polsce (1652-2002), II Prowincja krakowska i litewska. - Kraków: Instytut Wydawniczy Księžy Misjonarzy “Nasza Przeszłośc”, 2002. - 10, 13-16 s.

${ }^{4}$ Rosiak S. Prowincja Litewska sióstr miłoserdzia. - Wilno, 1933. - 5-6, 143-145 s.

5 Sienczak B. Zgromadzenie Sióstr Miłosierdzia św. Wincentego a Paulo w Polsce (1652-2002), II Prowincja krakowska i litewska. - Kraków: Instytut Wydawniczy Księžy Misjonarzy "Nasza Przeszłośc”, 2002. - 10, 13-16 s.

${ }^{6}$ Halat M. Obowiązki Sióstr Miłoserdzia w świetle dokumentów, Medycyna Nowožytna / Polska akademia nauk, Instytut historii nauki, Studija nad kulturą medyczną, Tom 6 - Zeszyt 2. - Warszawa, 1999. - 153 s.

7 Rosiak S. Prowincja Litewska sióstr miłoserdzia. - Wilno, 1933. - 5-6, 143-145 s. 
noteikumus. Vincenta de Paula pašrocīgi labotais teksts tika iesniegts Parīzes arhibīskapam, lai to apstiprinātu. Pēc nelielām izmaiñām teksts tika publicēts 1672. gada 5. augustā kā Žēlsirdīgo māsu - nabadzīgo un slimo kalpoņu - noteikumi. ${ }^{8}$

Žēlsirdīgās māsas aprūpēja nabagus un cietējus, par to izpelnoties sabiedrības vispārēju cieņu. Ar laiku viņu darbs tika atzîts ne tikai Francijā, bet arī citās valstīs. Kustība sasniedza arī Latvijas teritoriju. Neatkarīgi no valsts, kurā darbojās māsas, vin̄ām bija jāievēro apstiprinātie uzvedības un darbības noteikumi (Regula), kas bija pārtulkoti vairākās valodās. ${ }^{9}$

Krāslava ir Vincenta de Paula žēlsirdīgo māsu apvienības šūpulis Latvijā.

1754. gadā bīskaps Antonijs Ostrovskis uzaicināja uz Krāslavu lācariešus - katoḷu priesteru kongregāciju, kuru dibināja priesteris Vincents de Paula 17. gs. Parīzē. 1789. gadā Krāslavā tika uzcelts sieviešu klosteris. Tā paša gada 4. septembrī, atbraukušas no Varšavas (Polija), savu labdarību uzsāka Vincenta de Paula apvienības žēlsirdīgās māsas, sauktas par lācarietēm, kā arī par vincentīnietēm. ${ }^{10}$ Latvijas teritorijā žēlsirdīgās māsas tika uzaicinātas uz Krāslavu (Krasław), kur atradās misionāru priesteru valdes vadības patvērumā un pakḷāvās bīskapijas priekšniecībai. ${ }^{11}$

Pirmās māsas, kas ieradās, bija Juzefa Krasnodembska (Józefa Krasnodębska), Marja Skurevičuvna (Marja Skórewiczówna) un Rozalja Kubešovska (Rozalja Kubeszowska). Māsu darbs tika dažādi atbalstīts. Grāfiene Augusta Plātere (Augusta z Ogińskis Broel Platerowa, 1724-1791) nodibināja Žēlsirdīgo māsu fondu, ziedojot māsu uzturēšanai 100 tūkstošus zlotu. ${ }^{12}$ No š̀ fonda māsas saņēma speciālu dokumentu (1824. gada 20. septembra konsistorijas rīkojums Nr. 1997). ${ }^{13}$ Jau pēc pirmās māsas ierašanās Augusta Plātere savā testamentā ierakstīja: "Ja kāda slikta pasaules

8 Sienczak B. Zgromadzenie Sióstr Miłosierdzia św. Wincentego a Paulo w Polsce (1652-2002), II Prowincja krakowska i litewska. - Kraków: Instytut Wydawniczy Księžy Misjonarzy “Nasza Przeszłośc”, 2002. - 10, 13-16 s.

9 Turpat.

10 Halat M. Obowiązki Sióstr Miłoserdzia w świetle dokumentów, Medycyna Nowožytna / Polska akademia nauk, Instytut historii nauki, Studija nad kulturą medyczną, Tom 6 - Zeszyt 2. - Warszawa, 1999. - 153 s.

11 Lietuvos Valstybes istorijos archyvas, 604. f., 1. apr., 11490. b., 11.

12 Rosiak S. Prowincja Litewska sióstr miłoserdzia. - Wilno, 1933. - 5-6, 143-145 s.

13 Brežgo B. Latgola dažu 16.-19. gs. dokumentu gaismā. - Rēzekne, 1938. - 12. 1pp. 
likteņa pagrieziena dēḷ žēlsirdīgās māsas netiks uzturētas šajā valstī, tad Polijas zemju teritoriju labumos ir jāizveido fonds māsu uzturēšanai vai 100 tūkstošus zlotu pārsūtīt uz tuvāko Žēlsirdīgo māsu māju, bet ja poḷu zemē nebūs saglabājušās māsu mājas, tad šo summu atgriezt vīriešu kārtas līdzgaitniekiem."'14

Pret māsām labvēlīgi izturējās ne tikai fonda dibinātāja, bet arī viņas pēcteči: Augusts Hijacenti (August Hijacenty) un viņa sieva Anna (Anna z Rzewuskich Platerów), ${ }^{15}$ kā arī viņu mantinieks Augusts Plāters. Viņš 1790. gada 20. augustā žēlsirdīgo māsu pilnā rīcībā atdeva Pukenišku pusmuižu. ${ }^{16}$ 1796. gada 9. septembrī Plātera ǵimene palielināja vietējā nama apgādi, nodrošinot māsas ar mežu un aramzemi. Radās arī jauni labvēļi. 1816. gadā Ignacijs un Kataržina Ivanovski (Ignacy i Katarzyna Iwanowski) uzdāvināja namam 25000 sudraba rubl̦u. Dāvinājums deva iespēju žēlsirdīgajām māsām paplašināt savu darbību. ${ }^{17}$

Ar laiku tika palielināts arī māsu skaits. 1843. gadā Krāslavā strādāja jau astoņas žēlsirdīgās māsas: vecākā māsa Anna Rogojska (Аннa Рогойска), Konstance Mihailova Kvintuvna (Констанция Михайлова Квинтувна), Johanna Aleksandrova Taguševska (Йоганна Александрова Тагушевска), Jozefa Petrova Mikulovska (Йозефа Петрова Микуловская), Tekla Josifovna Malinovska (Текля Иосифовна Малиновска), Bogumila Antonova Berthovičevna (Богумила Антонова Бертховичевна), Benigna Teofileva Karazovska (Бенигна Теофилева Каразовска) un Faustina Stefanovičevna Gil̦arova (Фаустына Стефановичевна Гилярова). ${ }^{18}$

Māsas pievērsās labdarībai un audzināšanai. 1789. gadā grāfiene Augusta Plātere Krāslavā uzcēla pirmo slimnīcu, kurā žēlsirdīgās māsas kalpoja nabagiem un slimajiem. ${ }^{19}$

14 Sienczak B. Zgromadzenie Sióstr Miłosierdzia św. Wincentego a Paulo w Polsce (1652-2002), II Prowincja krakowska i litewska. - Kraków: Instytut Wydawniczy Księžy Misjonarzy "Nasza Przeszłośc”, 2002. - 10, 13-16 s.

15 Schletz A. Zarys historyczny Zgromadzenia Sióstr Miłoserdzia w Polsce. Kraków, 1960. $-9 \mathrm{~s}$.

16 Brežgo B. Latgola dažu 16.-19. gs. dokumentu gaismā. - Rēzekne, 1938. - 12. 1pp.

17 Schletz A. Zarys historyczny Zgromadzenia Sióstr Miłoserdzia w Polsce. Kraków, 1960. -9 s.

18 Нацыянальны гістарычны архіу Беларусі, 2638 ф., 1 оп., 772 д., 26 л.

19 Gedroyc F. Zapisi do dziejow szpitalnictwa w dawnej Polsce. - Warszawa: F. Gedroyc, 1908. - 34 s. 
Slimnīcai tika atvēlēta skaista mūra ēka ar kapliču. ${ }^{20}$ Tā bija paredzēta zemnieku, pilsētas iedzīvotāju un bāreņu ārstēšanai un kopšanai. Sākotnēji tika pieņemti 60 pacienti. ${ }^{21}$ Slimnīcu apmeklēja vietējā priekšniecība un daži slaveni cilvēki, kuri, konstatējot kārtību un šai iestādei atbilstīgo iekārtojumu, kā arī sniegto atbalstu nabagiem, to apdāvināja. ${ }^{22}$

Vēlāk, 1793. gadā, Krāslavā, klostera apkārtnē, tika organizēta meiteņu skola. ${ }^{23}$ Tas bija otrs cēls uzdevums, kam pievērsās žēlsirdīgās māsas, izglītošana un audzināšana. ${ }^{24}$

Skolā bija divas nodaḷas. Pirmā bija paredzēta meitenēm, kuru vecāki gribēja, lai viņu meitas apgūtu ticības mācību. ${ }^{25}$ Māsu svarīgākais uzdevums bērnu audzināšanā bija "apgaismot viṇu prātu": pirmkārt, iemācīt Dieva lūgšanas, Dieva un baznīcas baušlıus, kristiešu ticības rakstus, Svēto sakramentu un citus jautājumus, kas ir jāzina grēku izpirkšanai. Bērnus gatavoja Svētā sakramenta pieņemšanai, grēku sūdzēšanai un mācīja, kā pieņemt Svēto sakramentu, piedalīties Svētajā Misē, kā lūgt Dievu, kādas lūgšanas jālasa no rīta un vakaros, lai bērni agri varētu pierast pie baznīcas tradīcijām. Visu to māsas mācīja no katķisma grāmatas. ${ }^{26}$

Otrā skolas nodaļa bija paredzēta meitenēm, kuras pēc dažādu ticības jautājumu apguves turpināja skoloties, lai iemācītos mājturību. Meitenēm pasniedza arī vēsturi, aritmētiku, poḷu valodu, kā arī atsevišksi - franču un vācu valodu, ǵeogrāfiju, vispārējo vēsturi, klavieru un ǵitāras spēli. Māsu pienākums bija pieradināt meitenes darbam virtuvē, mājturībai, šūt un izšùt, lai katra zinātu, kā patstāvīgi veikt šos darbus.

20 Broel-Plater L. Kraslaw / Nakladem autora. - Londyn, 1975. - 40 s.

${ }^{21}$ Schletz A. Zarys historyczny Zgromadzenia Sióstr Miłoserdzia w Polsce. Kraków, 1960. - $9 \mathrm{~s}$.

22 Lietuvos Valstybes istorijos archyvas, 604. f., 1. apr., 11490. b., 11.

23 Vīksna A. Latgales ārsti un ārstniecība (1772-1918). - Latvijas Universitāte, 2004. - 48. lpp.

24 Schletz A. Zarys historyczny Zgromadzenia Sióstr Miłoserdzia w Polsce. Kraków, 1960. - 51-55 s.

25 Sienczak B. Zgromadzenie Sióstr Miłosierdzia św. Wincentego a Paulo w Polsce (1652-2002), II Prowincja krakowska i litewska. - Kraków: Instytut Wydawniczy Księžy Misjonarzy “Nasza Przeszłośc”, 2002. - 10, 13-16 s.

26 Lietuvos Valstybes istorijos archyvas, 604. f., 1. apr., 11720. b., 147.-160. 
Galvenais audzināšanas mērķis bija agri bērniem iemācīt nevainības nozīmi un stipru dievbijību. Pēc iespējas biežāk audzēknēm bija jāskaidro par dievbijību, par grēku nepiel̦aušanu, godīgumu un kārtību, lai bērni censtos saglabāt tieši šīs īpašības un pēc iespējas mazāk grēkotu, un būtu paklausīgi. Meitenēm tika ieaudzināta arī kautrība. ${ }^{27}$

Krāslavā 1808. gadā šajā skolā uzturējās 42 jaunkundzes, no kurām tikai 22 par mācībām samaksāja aptuveni 100 rubḷu katra. Pārējās pilnībā uzturēja māsu apvienība. Mācību priekšmetus pasniedza žēlsirdīgās māsas, bet franču un vācu valodas nodarbībām tika algoti speciālisti. 1809. gadā māsu audzināšanu vadīja vecākā māsa Marja Skurevičuvna (Marja Skórewiczówna). ${ }^{28}$ Pamatojoties uz noteikumiem, vecākajai māsai bija jābūt atbildīgai par bērnu audzināšanu un apmācību. Bez vecākās māsas atḷaujas neviena māsa netika pieņemta vai atlaista no darba. ${ }^{29}$ Kopā ar vecāko māsu strādāja arī citas māsas: Antoņina Kšenžopoḷska (Antonina Księżopolska), kas mācīja poḷu valodu un darbmācību, māsa Teresa Polonskka (Teresa Polońska), kas pasniedza darbmācību, zīmēšanu un izšǔšanu. Pie kopienas nepiederēja vācu valodas skolotāja Anna Venckaja (Anna Węckae) un franču valodas skolotāja Elžbeta Pidē (Elżbieta Pidet).

Vēlāk skolā mācījās 52 audzēknes. Tikai 24 maksāja par mācībām, bet pārējās, kuru vidū bija arī trīs pilsētas iedzīvotājas, uzturēja Žēlsirdīgo māsu apvienības fonds. Visas šīs meitenes bija cēlušās no muižnieku dzimtām, bet iestādē mācījās arī aptuveni desmit zemnieku izcelsmes skolnieces, kas apguva lasīšanas un pareizrakstības iemaņas, kā arī vienkāršus sieviešu darbus. ${ }^{30}$ Blakus skolai māsas uzturēja internātu (konviktu) meitenēm no aristokrātiskām aprindām. ${ }^{31}$ Jāatzīmē, ka bagāto ǵimeņu skolniecēm netika sniegta lielāka aprūpe un uzmanība nekā nabadzīgajām. Īpašu uzmanību pievērsa, lai bagātās meitenes neatstumtu un nepazemotu trūcīgās. ${ }^{32}$

${ }^{27}$ Lietuvos Valstybes istorijos archyvas, 604. f., 1. apr., 11720. b., 147.-160.

${ }^{28}$ Rosiak S. Prowincja Litewska sióstr miłoserdzia. - Wilno, 1933. - 5-6, 143-145 s.

29 Lietuvos Valstybes istorijos archyvas, 604. f., 1. apr., 11720. b., 147.-160.

30 Rosiak S. Prowincja Litewska sióstr miłoserdzia. - Wilno, 1933. - 5-6, 143-145 s.

31 Schletz A. Zarys historyczny Zgromadzenia Sióstr Miłoserdzia w Polsce. Kraków, 1960. - $9 \mathrm{~s}$.

32 Lietuvos Valstybes istorijos archyvas, 604. f., 1. apr., 11720. b., 147.-160. 
Apmeklētāji, kas ieradās skolā, ar atzinību atsaucās par māsu veikto audzināšanas darbu. ${ }^{33}$

1826. gadā Krāslavā izcēlās liels ugunsgrēks. Sadega daudzas mājas, arī meiteņu skola, tādēl iespējas uzṇemt bērnus mācību iestādē bija samazinājušās. ${ }^{34}$ Skolu likvidēja 1842. gadā, savukārt slimnīcā māsas strādāja, kalpojot cietējiem, līdz 1864. gadam (līdz kongregācijas likvidēšanai). Iestādes augstais līmenis bija zināms jau sen, un 1805. gadā, kad Gatčinā pie Pēterburgas (Krievijā) tika nodibināts Žēlsirdīgo māsu nams, viena no vietējām māsām Antoṇina Kšenžopoḷska piedalījās ekspedīcijā, lai iepazīstinātu ar savu pieredzi. ${ }^{35}$

1843. gada 17. jūlijā Krievijas imperators izdeva pavēli, kurā teikts, ka, balstoties uz Sabiedriskās aizgādības maǵistratūras rīkojumu, nodrošinās māsas ar atbilstīgām telpām, apkuri, apgaismojumu un ēdamo, kā arī dos naudu. No piešksirtajiem līdzekḷiem māsas varēs atstāt sev daļu naudas drēbēm vai izlietot citiem nolūkiem. Par to viņas piedalīsies slimo, nabago un veco cilvēku kopšanā labdarības iestādēs, kur māsām jāveic šādi pienākumi: uzraudzes, atslēgu glabātājas, slimnieku kopējas darbs un jāpilda citu amatu pienākumi labdarības iestādēs. Tās māsas, kuras negribēs izmantot šo monarha augstsirdību, ir jāatzīst par nederīgām, un tām tiks pārtraukts jebkurš valdības atbalsts. Tāpēc no katras žēlsirdīgās māsas bija jāpieņem rakstisks iesniegums, kurā māsai jāuzrāda, kurā Sabiedriskās aizgādības maǵistratūras iestādē viṇa vēlēsies strādāt, par to jāpaziṇo līdz 1843. gada. 1. oktobrim, lai laikus saplānotu māsu uzturēšanai nepieciešamo naudas summu, kuru tās saņems no 1844. gada 1. janvāra.

Šis rīkojums tika aizsūtīts visiem klosteriem. To saņēma arī žēlsirdīgas māsas Krāslavā. Tajā brīdī, 1843. gadā, klostera priekšniece Krāslavā bija Anna Rogojska. ${ }^{36}$

1843. gadā Krāslavas klosterī (no atskaites par 1843. gada 14. oktobri var secināt) strādāja šādas žēlsirdīgās māsas: klostera priekšniece Anna Rogojska (iestājās apvienībā 1823. gadā Viḷnāā, bet Krāslavā pildīja priekšnieces pienākumus no 1842. gada), Konstance Mihailova Kvintuvna, Johanna Aleksandrova Taguševska, iestājās apvienībā 1815. gadā, Krāslavas

33 Rosiak S. Prowincja Litewska sióstr miłoserdzia. - Wilno, 1933. - 5-6, 143-145 s.

34 Broel-Plater L. Kraslaw / Nakladem autora. - Londyn, 1975. - 40 s.

35 Rosiak S. Prowincja Litewska sióstr miłoserdzia. - Wilno, 1933. - 5-6, 143-145 s.

36 Нацыянальны гістарычны архіу Беларусі, 2638 ф., 1 оп., 772 д., 12-13 л. 
namā viṇa bija no 1836. gada, strādāja tieši ar slimniekiem, Jozefa Petrova Mikulovska, Tekla Josifovna Maļinovska, Krāslavā viņa uzturējās no iestāšanās brīža kongregācijā, Bogumila Antonova Berthovičevna, Benigna Teofileva Karazovska un Faustina Stefanovičevna Giḷarova, par ekonomi no 1834. gada strādāja Benigna Kornezuvna (Бенигна Корнезувна). ${ }^{37}$

Katrai māsai rakstiski bija jādod atbilde uz šo "monarha augstsirdību". ${ }^{38}$ Pamatojoties uz noteikumiem, žēlsirdīgās māsas pēc zvēresta nevarēja izstāties no kongregācijas bez speciālas atḷaujas (bija nepieciešams konsistorijas rīkojums). ${ }^{39}$ Tāpēc visas Krāslavā strādājošās žēlsirdīgās māsas atteicās strādāt labdarības iestādēs pēc Sabiedriskās aizgādības maǵistratūras rīkojuma. Katrai māsai bija rakstiski jāpaskaidro atteikšanās iemesls. Visām māsām tas bija vienāds: pamatojoties uz Regulu, visām māsām jāpaklaujas dotajam zvērestam, tāpēc viṇas bija gatavas izpildīt visus valdības rīkojumus, bet tikai ar savas priekšniecības atḷauju, kurai bija tiesības izrīkot attiecīgās māsas. ${ }^{40}$ Saskaņā ar 1843. gada rīkojumu viņām nemaksāja algu, tomēr māsu darbs slimnīcā turpinājās. Iestādes plašā ēka bija tukša. Daļu telpu māsas iznomāja privātpersonām, šādā veidā iegūstot iztikas līdzekḷus. ${ }^{41}$

Viena no māsām, Jozefa Petrova Mikulovska, nebija apmierināta ar šādu situāciju un uzrakstīja lūgumu par pases noformēšanu, lai aizbrauktu no Krāslavas. 1845. gada 11. augustā viņai tika izdota pase aizbraukšanai uz Podoḷskas guberņu. Saņēmusi pasi, žēlsirdīgā māsa atstāja klosteri. ${ }^{42}$

Žēlsirdīgās māsas 1863. gada janvārī sacelšanās laikā aktīvi piedalījās arī šajā kustībā (bruṇota sacelšanās pret Krievijas impērijas varu Polijā, Baltkrievijā un Lietuvā, lai atjaunotu pēc Polijas dalīšanas sagrauto Polijas-Lietuvas kopvalsti 1772. gada robežās), reliğiski sociālajam garam pievienojot darbu dzimtenes labā. Māsas dziedāja nemiernieku himnas, kā arī sacelšanās laikā slēpa personas, kuras varas iestādēm šksita

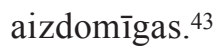

\footnotetext{
37 Нацыянальны гістарычны архіу Беларусі, 2638 ф., 1 оп., 772 д., 23 л.

38 Turpat, 1-2 л.

39 Lietuvos Valstybes istorijos archyvas, 604. f., 1. apr., 11488. b., 1.

40 Нацыянальны гістарычны архіу Беларусі, 2638 ф., 1 оп., 772 д., 12-13 л.

${ }^{41}$ Rosiak S. Prowincja Litewska sióstr miłoserdzia. - Wilno, 1933. - 5-6, 143-145 s.

42 Нацыянальны гістарычны архіу Беларусі, 2638 ф., 1 оп., 772 д., 71-72 л.

43 Rosiak S. Prowincja Litewska sióstr miłoserdzia. - Wilno, 1933. - 5-6, 143-145 s.
} 
Requty pospolite Repromadzenia ciosts mitovierdzia. MW

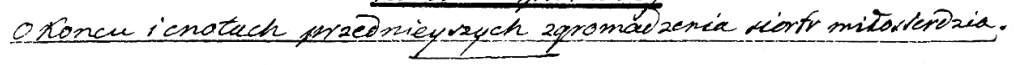

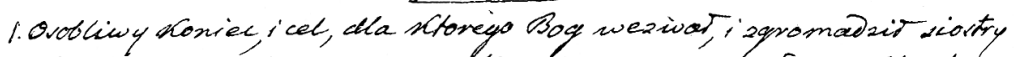

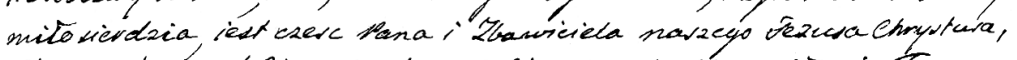

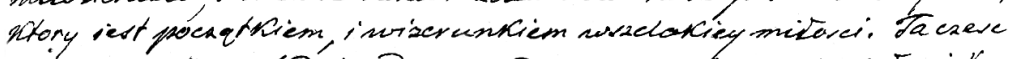

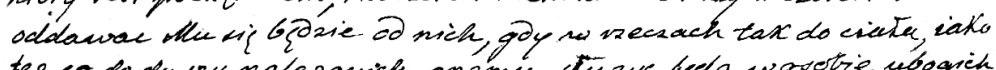
ter co do durzy nale rqcych, oneme thuze bedq worebie wbogrich, chorych, wiermiow, sicrot, lub innyeh oxob thtore dla witadu nie.

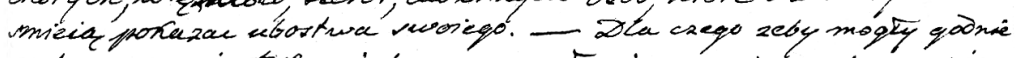

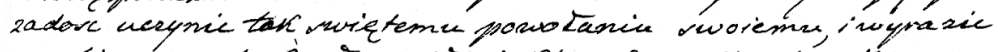

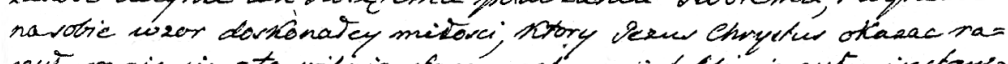

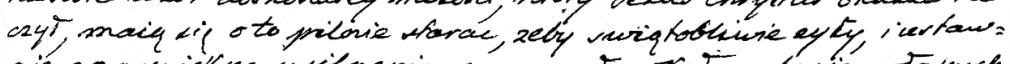

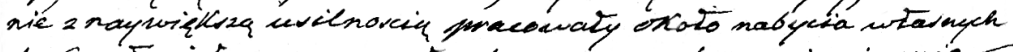

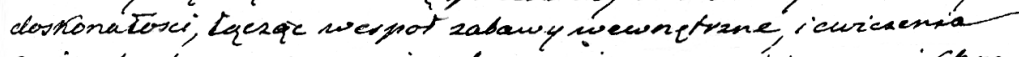
zyeia decchourneqo, zpovierzchownemi sprawam,' precami Chras:

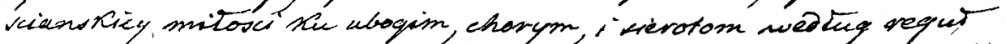

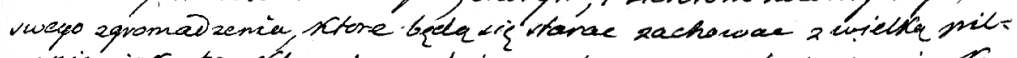

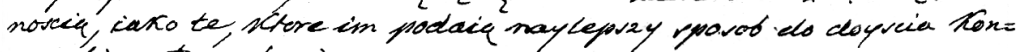
ca vobic wtyón stanie przesnacsonego.

2. I lubo spromadzenie ich nie iest zaden Raton, an bydz more, po: nievar obouiquk ith powotania pogobecic it 2 Alauzura izator. nym zyciem nie nnogq, atoli poniewas na niebespicsenstwa vuri= ta bardxicy a wyitawione nizeli sakon nice, nie macic swyceay=

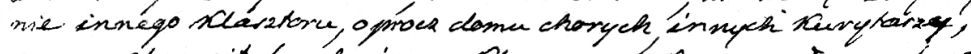

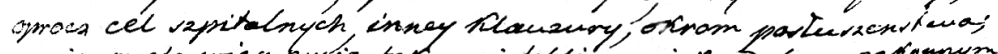
maiq prato wierc kycie tax pwiqtobliwe iat goyby w earounym

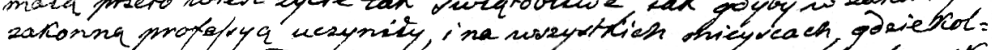

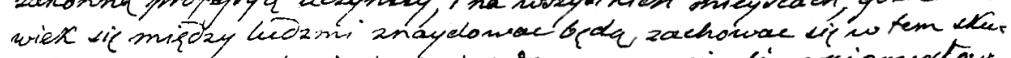

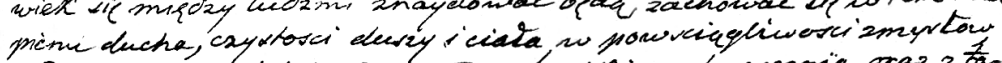

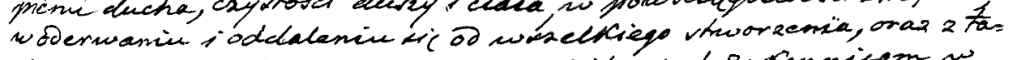
Diem zbudowaniem, cakie pryowite iest zatonesicom w ith Marzhorze.

3. Riniwora necs
Žēlsirdīgo māsu - nabadzīgo un slimo kalpoṇu - noteikumu (Regulas) oriǵināla kopijas fragments

Žēlsirdīgo māsu kārta atradās bīskapijas (bīskapa) pakḷautībā un nevienai nebija tiesību patvaļīgi rīkoties bez priekšniecības ziņas. Tuvākajam priekšniekam vienmēr bija jāzina viss, kas darāms klosteros, un par katru pārkāpumu bija jāziņo klostera priekšniecei. ${ }^{44}$ Tāpēc māsu

${ }^{44}$ Lietuvos Valstybes istorijos archyvas, 604. f., 1. apr., 11490. b., 14. 
atklātā darbība, kas izpaudās nemiernieku atbalstīšanā, kḷuva zināma krievu žandarmērijai. 1864. gada augustā uz Krāslavu, lai veiktu pārbaudi, no Viḷnas tika deleǵēts Iekšlietu ministrijas speciālo lietu ierēdnis Storoženko (Storoženko). Pārbaudot māsu personas datus un sarakstus, viņš ievēroja, ka Konstance Kvintuvna (Konstancija Kwintównq) nevēlējās skatīties uz viṇu. Šāda uzvedība ierēdnim likās dīvaina, un viņš izdeva rīkojumu veikt detalizētu pārbaudi. Turpmākās izmeklēšanas gaitā atklājās, ka īstā Kvintuvna bija mirusi pirms dažiem gadiem, savukārt māsa, kurai bija personas apliecība uz viṇas vārda, patiesībā bija Franciška Služko-Cjapiņska (Franciszka Słužko-Ciapińska), turpinot noskaidrošanu, tika konstatēts, ka arī šie personas dati nav precīzi, un īstais vārds ir Franciška Služko-Uspenska. Izrādījās, ka viņa bija vainīga vēl vienā pārkāpumā - nelegāli iestājusies apvienībā bez administratīvo iestāžu atḷaujas. Vispār Krāslavā tika atklāti vairāki pārkāpumi personāla jautājumos, un pārbaudes laikā konstatēja, ka tikai piecas māsas tur uzturējās legāli. ${ }^{45}$

Apspriežot visus notikumus, 1864. gada 31. oktobrī Vil̦nas Romas katoḷu garīgajā konsistorijā tika izdots rīkojums "Par Krāslavas Žēlsirdīgo māsu mājokḷa likvidēšanu”. Pēc novada žandarmu korpusa priekšnieka rīkojuma apakšpulkvedis Nolds (фон Нольдс) tika komandēts uz Krāslavu slēgt Žēlsirdīgo māsu mājokli un kontrolēt, lai māsas nosūtītu uz vietām, no kurienes viņas bija ieradušās Krāslavas klosterī. Apakšpulkvedis aizsūtīja māsas uz Vil̦ņu. Tur tika nolemts, ka māsas, kuras bija atsūtītas no Varšavas darbam Krāslavā, jāaizsūta atpakal̦ uz Varšavu, bet pārējās jāievieto sieviešu klosteros Viḷnāa un Dombrovskas kundzes patvērumā. ${ }^{46}$ 1864. gada 16. novembrī uz Varšavu tika aizsūtīta žēlsirdīgā māsa Franciška Služko-Cjapinska (īstais vārds Služko-Uspenska, СлужкоУспенская) un māsa Ustīnija Mižlevičuvna (Устиния Мижлевичувна). ${ }^{47}$ Pārējās māsas - Anna Rogojska, Benigna Kornezuvna, Johanna Tarušele (Иоганна Тарушель) un Tekla Maļinovska - tika izmitinātas klosterī Viḷnā (Lietuvā). ${ }^{48}$ Savukārt māsa Anna Rogojska (63 gadus veca) un

\footnotetext{
45 Rosiak S. Prowincja Litewska sióstr miłoserdzia. - Wilno, 1933. - 5-6, 143-145 s.

46 Lietuvos Valstybes istorijos archyvas, 694. f., 5. apr., 5002. b., 1.

47 Turpat, 6.

48 Turpat, 9.
} 
Johanna Tarušele (70 gadus veca) 1864. gada 16. oktobrī slimības dēḷ tika ievietotas hospitālī Savičā (Viḷnāā), jo veselības stāvokḷa dēḷ viṇām bija nepieciešama citu māsu palīizība. ${ }^{49}$

Māsu mītnē Krāslavā iekārtojās krievu policija, bet kapliča tika pārvērsta par pareizticīgo baznīcu. ${ }^{50}$

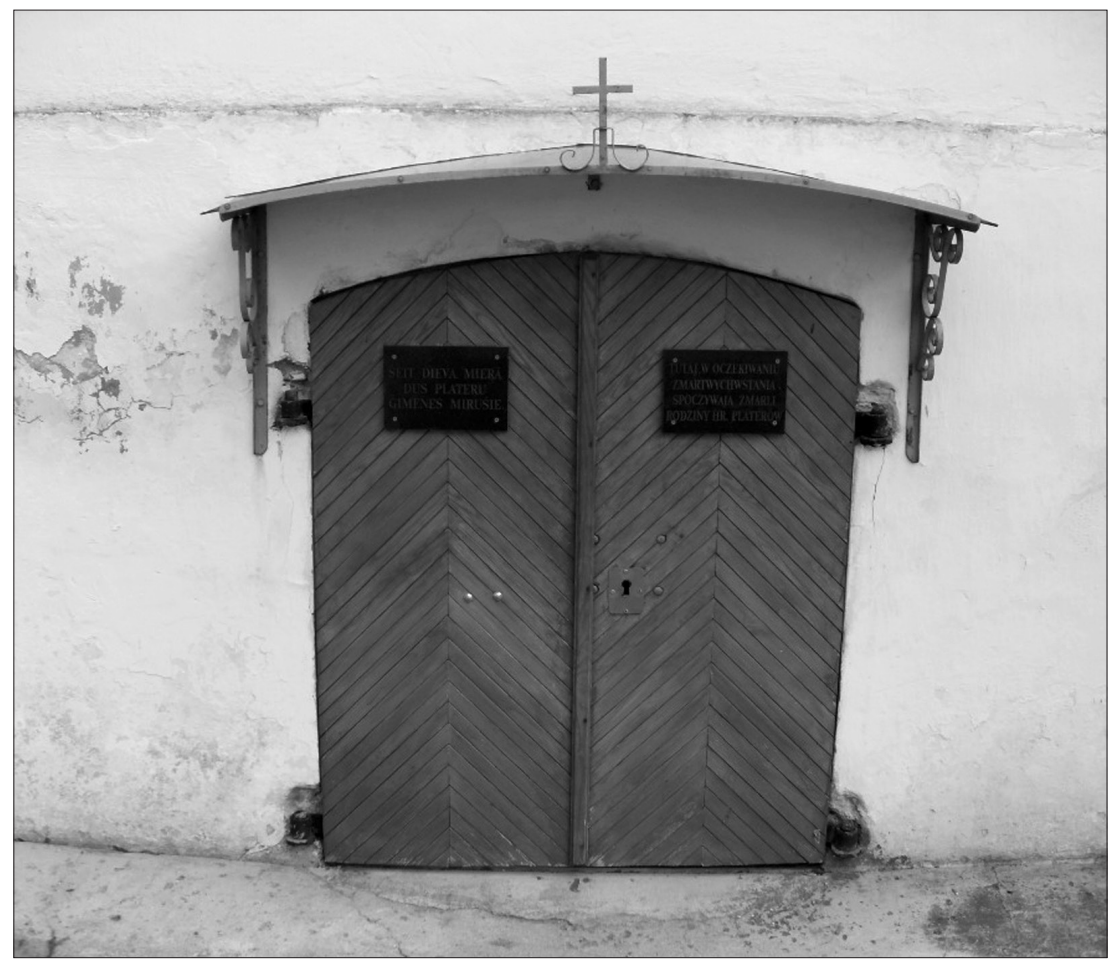

Aiz šīm Krāslavas Svētā Ludvika Romas katoḷu baznīcas durvīm atrodas Plāteru ǵimenes kapliča, 2011. gads

Žēlsirdīgo māsu pieminai Krāslavas Romas katoḷu baznīcā uz pirmā pīlāra labajā pusē ir epitāfija, kurā rakstīts: "D.O.M. Ku Wiecznej Pamięci Sprowadzonych do Krasławia pzež S. P. Augustę z X. X. Oginskich Broel

49 Lietuvos Valstybes istorijos archyvas, 694. f., 5. apr., 5002. b., 19.

50 Zeile P. Latgales kultūras vēsture. - Rēzekne: Latgales kultūras centra izdevniecība, 2006. - 324. lpp. 
Platerowę w 1779. Sióstr Miłoserdzia S go Wincentego które się dor. 1864 chorym, ubogim i sierotam poswięcaly. Panie uzbudž nasladowców ich dobroozynnej dziatalnosci!' Krāslavas Romas katolıu baznīcā tika apglabāti Plāteru ǵimenes locekḷi. Uz apbedīšanas vietas durvīm ir uzraksts: “Šeit Dieva mierā dus Plāteru gímenes mirušie. Tutal w oczekiwaniu zmartwychwstania spoczywaiq zmarli rodziny HR. Platerów”. Krāslavas pilsētas katoḷu kapu vecajā sektorā ir žēlsirdīgo māsu kaps ar čuguna krustu, uz kura lasāms uzraksts: "Tu sióstry miłosierdzia prosza o wieczne odpocznienie" un uz akmens pamata izcirsti vairāki riņksi, kurus varētu salīdzināt ar rožukroni. Diemžēl šeit nav norādīts, kura žēlsirdīgā māsa šajā vietā apglabāta.

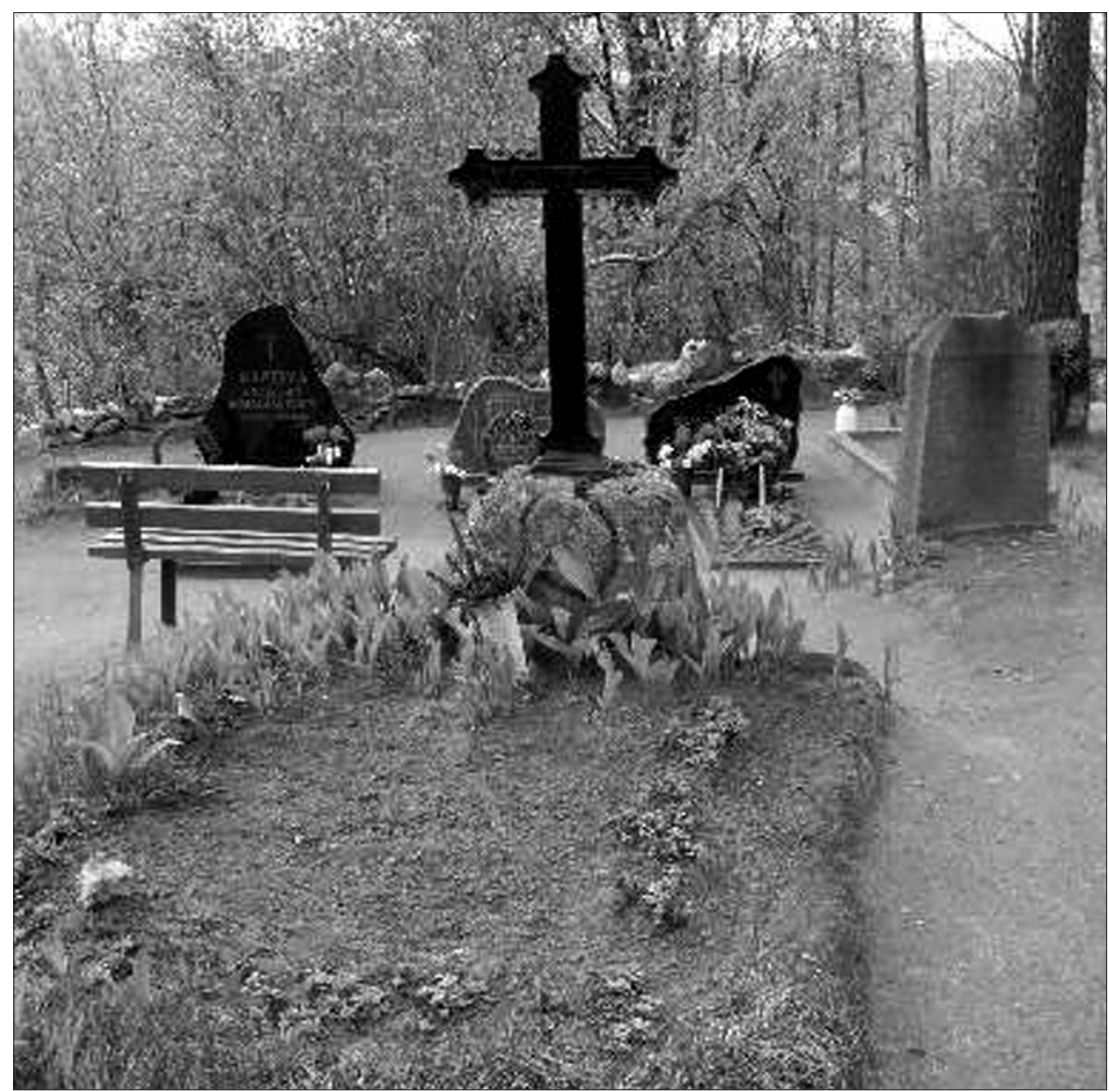

Vincenta de Paula apvienības žēlsirdīgo māsu kaps katoḷu kapsētā Krāslavā, 2011. gads 
○

cher vis

20. 0.

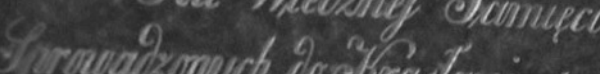
peornef Sinnuper o-

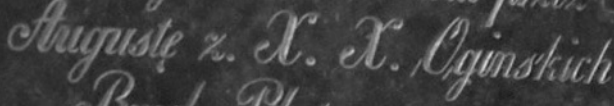

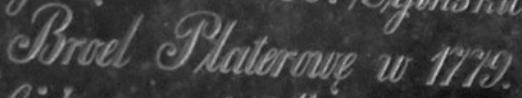

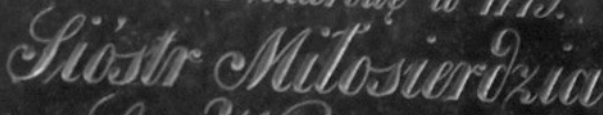
C.ge Misecentegro. Wetore sie do x. 1864 chorym, ulogim $i$ sierotom posnicecatiy. Panie wathici naslaconcosio.

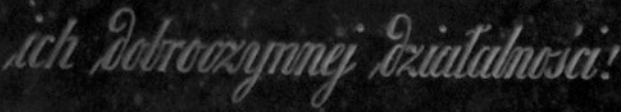

C , 


\section{Māsu uzvedības un darbības noteikumu apraksts}

Gan slimnīcā, gan skolā māsas strādāja saskaṇā ar Parīzes arhib̄̄skapa pieņemtajiem un apstiprinātajiem noteikumiem (Regulu). ${ }^{51}$

Lietuvas Valsts vēstures arhīvā Viḷnā ir saglabāts Vincenta de Paula apvienības žēlsirdīgo māsu Regulas rokraksts poḷu valodā. Šā dokumenta apraksts latviešu valodā pirmo reizi bija publicēts arī Latvijā. Piedāvājam ieskatu Regulas punktos.

Regula sastāv no 11 nodaḷām, kurās aprakstīti māsu uzvedības un darbības noteikumi.

Pirmās nodaļas nosaukums ir "Par tikumību”. Nodaḷā teikts, ka priestera Vincenta de Paula žēlsirdīgo māsu apvienība nav uzskatāma par mūķeņu ordeni tāpēc, ka žēlsirdīgās māsas vairāk pakḷautas pasaulīgiem draudiem nekā mūķenes. Žēlsirdīgo māsu pienākums - apmeklēt slimniekus mājās - viṇas pakḷauj pasaulīgiem draudiem. Bet visās vietās, kur māsas atrodas, viņām jāsaglabā tāds garīgais un fiziskais stāvoklis, kurš jāievēro mūķenēm savā orden̄̄. Norādīts, ka galvenais mērķis, ar kuru Dievs apvienoja žēlsirdīgās māsas, ir Dieva godāšana, jo viņš visiem cilvēkiem ir piemērs un mīlestības avots. Lai tam sekotu, galvenais māsu pienākums ir tikumīgi dzīvot un apvienot garīgos uzdevumus ar kristīgo mīlestību pret nabadzīgajiem un slimajiem.

Šajā nodaḷā tika norādītas trīs tikumības izpausmes, kuras māsām obligāti jāievēro: miers, vienkāršība un mīlestība. Šie tikumības virzieni tika pielīdzināti trim gara spēkiem, kas veidoja māsu dvēseli, misiju un stāvokli sabiedrībā. Lai saglabātu savas dvēseles mieru, māsām jāatturas kā no garīgiem pārdzīvojumiem, tā arī no izklaidēm. Viṇām jādzīvo ar apziņu, ka šāds dz̄̄ves stils ir labāks nekā dz̄̄vošana tikai savam labumam. Māsām stingri aizliegts būt piesaistītām pie dzīvesvietas, izklaidēm un cilvēkiem, pat pie saviem radiniekiem un mācītājiem. Māsām vienmēr jābūt pakḷautām un visu laiku jāatceras, ko teica Dievs: "Mēs nevērtējam sevi, ja nepalaidīsim tēvu, māti, brāḷus, māsas un neaizmirsīsim par sevi un par visām pasaules lietām, lai atdarinātu Jēzu Kristu”. Māsām, lai iegūtu Dieva mīlestību, jābūt gatavām pieņemt grūtības un nelaimes, zobgalības

51 Sienczak B. Zgromadzenie Sióstr Miłosierdzia św. Wincentego a Paulo w Polsce (1652-2002), II Prowincja krakowska i litewska. - Kraków: Instytut Wydawniczy Księžy Misjonarzy “Nasza Przeszłośc”, 2002. - 10, 13-16 s. 
un citas ciešanas pat no tiem, kam viņas izdarīja kaut ko labu. Lai saņemtu Dieva mīlestību, māsām obligāti bija jātic savai misijai un jāievēro savas darbības un uzvedības noteikumi.

Nākamajā nodaḷā "Par nabadzību” teikts, ka māsām jāslavē Jēzus Kristus nabadzība, jādzīvo trūkumā un jāuzskata sevi par nabago kalponēm. Tāpēc nevienai no vin̄ām nepiederēs māja un kas cits, ko gribētu saglabāt un izmantot. Māsām bija aizliegts izmantot, pelnīt un aizņemties naudu. Tāpat viņām nebija aț̣auts ņemt kādas mantas no cilvēkiem bez vecākās māsas atḷaujas. Lai māsas nepārkāptu šos noteikumus, vecākajām māsām katru nedēlu bija jāaptaujā māsas par viņu vajadzībām un jānodrošina ar visu nepieciešamo. Tomēr, ja vecākā māsa uzskatīja, ka konkrēta manta bija lieka, viņa bija tiesīga to atņemt. Māsām bija aizliegts apvainoties, ja kādu mantu atdeva citai māsai. Š̀̃ rīcība trenēja māsas paklausībā un pacietībā.

Gadījumā, ja māsa kaut ko paṇēma bez vecākās māsas atḷaujas un citas māsas to zināja, tad par šo notikumu nebija pieņemts runāt publiski, bet obligāti vajadzēja paziņot galvenajai māsai. Tāpat māsām bija jācenšas nepazaudēt un nesabojāt mantas. Pastāvēja uzskats, ka varētu būt negatīvas sekas, ja māsām būtu atḷauts pirkt audumus un šūt sev apǵērbu. Šī rīcība varētu izraisīt strīdus māsu vidū un sabojāt svētās apvienības darbību. Tāpēc tikai vecākām māsām bija atlıauts pirkt audumus vai apgēerbu māsām, piemēram, lakatiņus. Māsām obligāti bija jāvalkā vienāds un neuzkrītošs apǵērbs, tā apliecinot pieticību ne tikai dvēseles stāvokḷa līmen̄ì, bet arī nodrošinot kārtību apvienībā. Visām bija jāvalkā vienāds tērps: pelēka kleita ar platām piedurknēm un balta auduma cepurīte, dēvēta par korneti.

Apvienības māsām bija jāsaglabā sava svētā nabadzība arī slimības gadījumos. Nekādā gadījumā māsas nedrīkstēja parādīt savu neapmierinātību ārstēšanas vai ēdiena dēl̦. Ciešanu pārvarēšanu uzskatīja par lielu laimi. Pamatojoties uz iepriekš minēto, izriet, ka arī saslimušajām māsām bija jāēd tikai noteiktā laikā un vietā (klostera ēdnīcā). Māsām, kuras apmeklēja slimās biedrenes, bez vecākās māsas aț̣aujas bija aizliegts kaut ko pirkt un nest sirdzējām. Tāpat arī bez vecākās māsas aț̣ajas māsām bija aizliegts pieņemt dāvanas no "laicīgiem" cilvēkiem. Bija aizliegts ar̄̄ laist pie galda vai savā istabā svešas personas, pat sievietes. Šādi noteikumi māsām bija jāievēro, lai cilvēki neizmantotu viņiem nepiederošo labumu, kas pieder tikai māsām, nabagiem un slimiem, savu vajadzību apmierināšanai. 


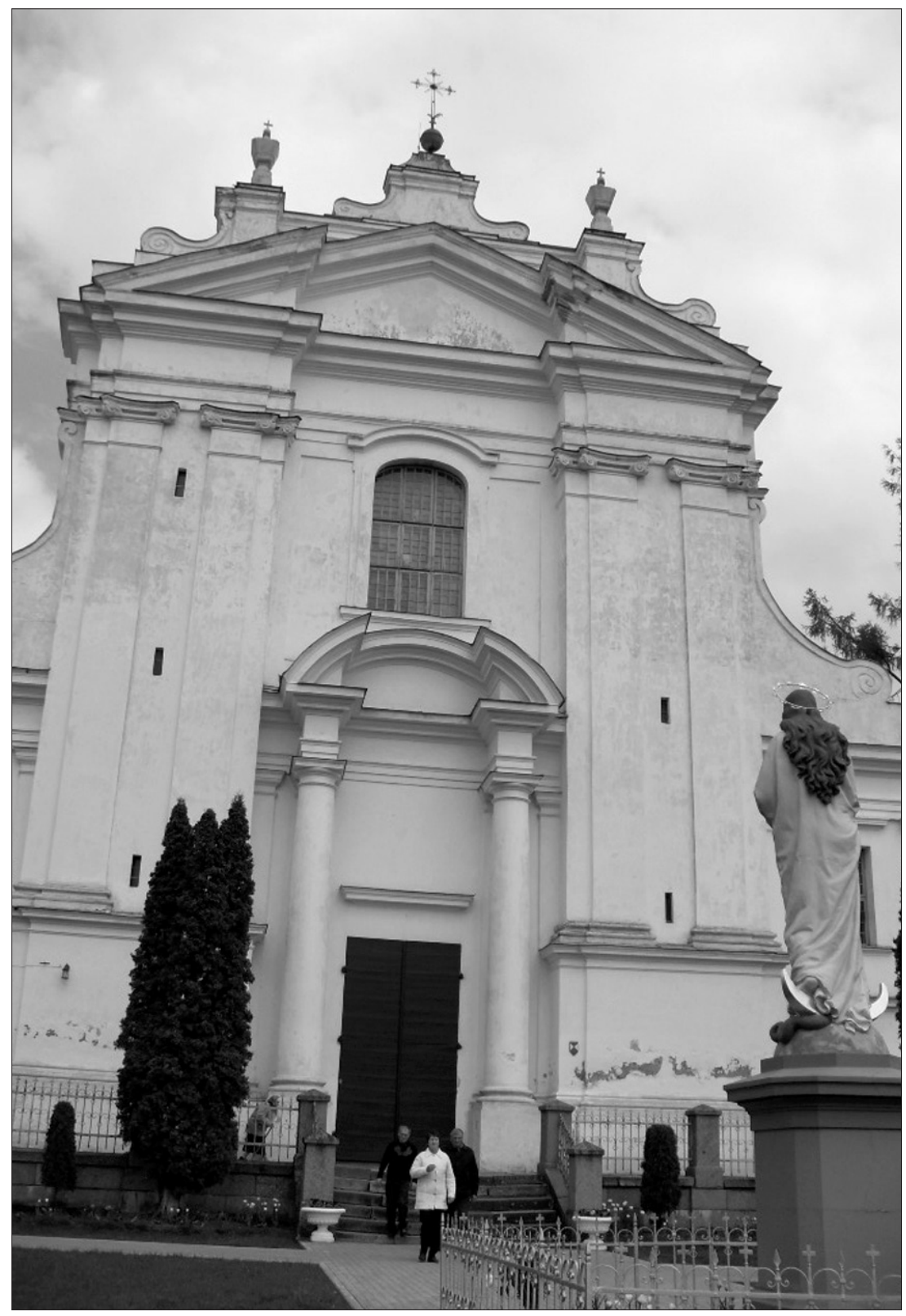

Krāslavas Svētā Ludvika Romas katoḷu baznīca, 2011. gads 
Nodal̦ā "Par tīrību" māsas tiek aicinātas saglabāt sava ķermeņa un dvēseles tīrību, dzīt projām no sevis visas domas, kas ir pretrunā ar šķ̄īstību, un stingri izvairīties no rīcības, kura varētu būt pārkāpuma iemesls. Māsām šīs prasības bija jāievēro, lai cilvēkiem nerastos priekšstats, ka viṇas nepieturas pie nevain̄̄guma. Negatīvi uzskati varētu izjaukt savienības darbību, tādēl bija jāizvairās no šādām sliktām īpašībām: vēlmes patikt citiem, godkārības, apǵērba baudīšanas, kā arī no pašpārliecības. Pat atpūtas brīd̄̄ vai sarunas laikā vin̄ām bija jāizvairās no jokiem, smiekliem un vieglprātības. Nebija atbalstāma arī skatīšanās pa logu, bez īpašas vajadzības laika pavadīšana ar svešiem cilvēkiem. Ikdienā māsām obligāti bija jārīkojas tā, lai neapvainotu "Dieva skatu". Tāpēc, ejot pa ielu, atrodoties baznīcā vai svešās mājās, it īpaši runājot ar pretējā dzimuma cilvēkiem, acu skatienam vienmēr jābūt vērstam uz zemi. Nebija vēlams, ka māsas bez vajadzības lieku reizi pieskartos cita citai, pat ja to darītu joka pēc vai kā simpātiju apliecinājumu. Šajā gadījumā tika atbalstīta distances saglabāšana citai no citas. Vien̄̄gi bija atḷauts apskaut mīlestības garā tās māsas, kuras tikko pieṇēma apvienībā; vai gadījumā, ja māsa atnāca no citām mājām vai atgriezās no ceḷojuma; samierināšanās gadījumā (šajā situācijā bija atḷauts nobučot vienai otru, bet tikai uz vaiga un stāvot ceḷos).

Māsām bija jācenšas novērst bezdarbību, kas uzskatāma par dažādu grēku avotu. Gadījumā, ja māsām nebija darba, viṇām vajadzēja lūgt vecāko māsu vai vecākās māsas asistenti atrast viṇām kādu nodarbošanos. Māsām bija aizliegts turēt mājdzīvniekus (piemēram, suṇus), kuri varētu būt bezjēè̄ịas laika pavadīšanas iemesls. Iziešana no mājas bez vecākās māsas atļaujas bija stingri aizliegta. Pirms iziešanas no mājas māsām vajadzēja paziņot vecākajai māsai kurp un kādā nolūkā dosies. Atbilstīgi noteikumiem māsām no mājas vienmēr jāiziet divatā. Gadījumos, ja māsa iziešanai no mājas nevarēja atrast otru māsu, jāṇem līdzi kāda meitene no skolas vai kāda jaunava, kura sekotu māsai visur līdzi. Tāpat pēc atgriešanās māsai jāinformē vecākā māsa, kur bijusi un ko darījusi. Bija stingri aizliegts apmeklēt un nodrošināt ar zālēm tos cilvēkus, kuri atradās šaubīgās vietās; runāt ar cilvēkiem, kuri saslimuši "netīras” rīcības dēḷ. Kas attiecas uz citiem slimniekiem, it īpaši pretējā dzimuma, māsām vienmēr jābūt uzmanīgām, iedodot viņiem zāles vai sniedzot tiem kādu citu palīdzību; māsas nedrīkstēja tuvināties viņiem pārāk cieši klāt, pat mirstošiem, sagatavojot tos nāves brīdim. Māsām bija stingri aizliegts laist 
savās istabās mācītājus, izņemot slimības gadījumos, bet tad kaut vienai māsai jābūt klāt. Tāda piesardzība bija jāievēro arī ārsta, aptiekāra, friziera un citu speciālistu slimas māsas apmeklēšanas laikā. Māsām bija aizliegts apmeklēt savus mācītājus vai citus garīdzniekus viņu mājās. Vīriešu klātbūtnē māsām vienmēr jāsaglabā mērenība vārdos un emocijās.

Tā kā mērenība ēšanā ne tikai labvēlīgi ietekmē cilvēka veselību, bet arī palīdz saglabāt gara tīrību, māsām vajadzēja censties ierobežot ēdiena daudzumu. Gadījumā, ja kādai māsai rodas ēstgriba, izņemot pusdienas vai vakariņas, vai māsa grib apēst kādu neparastu vai pārāk vienkāršu ēdienu, viņai jāprasa vecākās māsas atļauja. Bet neviena nedrīkstēja dzert vīnu bez priekšnieces atļaujas. Māsām bija jāievēro gavēnis dienu pirms visiem baznīcas svētkiem, kā arī visās piektdienās un otrdienās visa gada garumā, izņemot svētku dienas.

Nodaḷā "Par paklausību” aprakstīti noteikumi par paklausību priekšniecībai: māsām bija jāpakḷaujas savai priekšniecībai (kongregācijas misijai, jo tā ir apvienības tiešā priekšniecība), direktoriem, mācītājiem, kā arī vecākajai māsai. Priekšniecības uzdevumi vai rīkojumi jāizpilda tā, it kā pats Dievs būtu devis rīkojumu: "Kas jūs klausās - mani klausa, kas jūs noniecinās - noniecinās mani." Ar lielu godu māsām jāizturas pret visiem garīdzniekiem. Bija pieņemts, ja kāda māsa slikti pilda savus pienākumus, tad personai, kura to pamana, no savas puses nekas nav jāaizrāda, bet jāpaziņo priekšniecībai. Māsām bez vecākās māsas atḷaujas bija stingri aizliegts atvērt saņemtās vēstules un atklātnes (kaut arī tās bija viņām adresētas), korespondenci vispirms izlasīja vecākā māsa. Tāpat māsām bija aizliegts rakstīt vēstules bez vecākās māsas atļaujas. Vispirms sūtījums bija jādod izlasīt vecākajai māsai, lai tā iepazītos ar saturu. Bet šī kārtība neattiecās uz vēstulēm, kuras rakstīja māsas savai priekšniecībai. Vecākām māsām divas vai trīs reizes gadā bija jāraksta saviem priekšniekiem, lai informētu par savu un citu māsu darbību.

Nodạ̦ā "Par mīlestību un draudzību savā starpā” aprakstīts, ka māsām maksimāli jācenšas saglabāt savstarpējā vienotība, saskaṇa un abpusēja mīlestība. Savos ikdienas darbos māsām bieži bija jādomā un jāatkārto vārds "žēlsirdība”, kas nozīmē mīlestību. Gadījumā, ja kāda māsa apvainoja citu māsu, viņai nekavējoties, stāvot ceḷos, jālūdz piedošana (pēc iespējas - uzreiz, bet vēlākais laiks - vakarā pirms gulētiešanas). Bet otrai māsai bija jāpiedod, nomierinot lūdzēju, un arī pašai jānokrīt ceḷos. Š̄ rīcība 
uzskatāma par labāko veidu dusmu nomierināšanai. Pārmērīgas rūpes par sevi un savu veselību māsu vidū nebija atbalstāmas. Tāpēc slimības gadījumā māsām bija aizliegts lietot zāles, nolaist asinis un lūgt ārsta palīdzību bez vecākās māsas atļaujas. Izņēmuma gadījums varēja būt, piemēram, akūta epilepsijas lēkme.

Nākamajā nodaḷā "Par kalpotāju mīlestību un kopējas vienotības saglabāšanu" noteikts, ka māsām jāizvairās no pārāk ciešas draudzības savā starpā, jo tā var novest pie nelabvēlīgām sekām.

Lai gan saskarei starp māsām bija jābūt mīlestības piepildītai, viṇām tomēr jāizvairās no savstarpējas draudzības, kas var būt bīstama, jo spēj izraisīt mīlestības afektu. Māsām bija jāizvairās no šādas rīcības, lai neizsauktu kurnēšanu, kas izjauktu mieru un vienotību apvienībā. Māsām bija aizliegts runāt, apspriest un kritizēt apvienības valdi. Gadījumā, ja māsa aizmirst par saviem pienākumiem un izklaidējas sarunās vai aprunā citus, pārējām māsām jācenšas pārtraukt sarunu vai vispār nav jāklausās runātājā. Bet, ja māsa savu runu nepārtrauc, pārējām klātesošām ātri jābēg no viņas "līdzīgi, kā no čūskas". Klusēšana bija pieskaitāma pie galvenajām metodēm, lai novērstu dažus grēkus, kurus cilvēki var izdarīt ar savu "mēli". Jāklusē nodarbību laikā un no vakara dievkalpojuma līdz rīta Svētajai Misei (ap pulksten 7), un no pulksten diviem līdz trim pēcpusdienā. Ja gadījumā šajā laikā jārunā, tad tas jāizdara īsi un klusi. Klusums māsām bija jāievēro baznīcās un kapelā, slimnīcās, savās istabās, ēdamistabās, it sevišksi ēšanas laikā. Pat laikā, kad viņām bija atḷauts runāt savā starpā, māsām tomēr bija jāatceras, ka vienmēr jārunā mērenā balsī. To reglamentēja māsu noteikumi.

Nodạ̦ā "Par mīlestību pret nabagiem un slimiem” noteikts, ka māsām pašām ir jādod nabagiem ēdiens un zāles, jāizturas pret tiem ar žēlsirdību, maigumu, cieņu un dievišksumu, pat pret tādiem, kuri ir ļauni un nepatīkami. Ar lielu apzinīgumu māsām jākalpo slimniekiem un nabagiem, kuri izraisa vin̄ās riebumu. Šādā veidā māsām tika dota iespēja pārdzīvot lielākas ciešanas. Nesaprātīga žēlsirdība un mīlestība nepatīk ne tikai Dievam, bet arī tiem, kuri mēǵina to ieviest savā praksē. Tāpēc māsām tika aizliegts palīdzēt slimajiem bez priekšniecības atḷaujas, par spīti neapmierināto nabagu sūdzībām. Šajā gadījumā māsām tomēr bija jācenšas viņus nomierināt, parādīt savu līdzjūtību un kopā ar cietējiem nožēlot, ka nevarēs viṇiem palīdzēt. 
Tajā pašā laikā viņas piesaistīja arī citus cilvēkus, lai tie sniegtu nabagiem palīdzību. Ja pašām māsām rados bija trūcīgi tuvinieki, viņām bija jācenšas nepārkāpt mīlestības robežas - nelūgt nevienu cilvēku, lai palīdzētu radiniekiem bez vecākās māsas atļaujas. Māsām tika stingri aizliegts veikt slimnieku apskati naktī, izṇemot, ja sirdzējus apraudzīja savā māsu mājā un slimnīcā, kur dzīvoja pašas. Tika aizliegta bagāto cilvēku apkalpošana gan slimības, gan veselības gadījumos. Nebija atbalstāma ar̄̄ bagāto cilvēku kopšana slimības gadījumos, jo tā neatbilda žēlsirdīgo māsu noteikumiem, kuru mērksis bija nodrošināt palīdzību nabagiem. Gadījumā, ja nebija iespējas atrast ārstu vai feldšeri, māsas varēja palīdzēt arī bagātajiem, bet vispirms sniedzot palīdzību nabagiem. Bez priekšniecības atḷaujas māsām bija aizliegts n̦emt sev kalponi, kas palīdzētu veikt kādu darbu.

Par māsu garīgo audzināšanu, lai saņemtu Dieva mīlestību, ir aprakstīts nodaḷā “Par garīgiem ieradumiem”. Māsām cītīgi bija jāpilda garīgie uzdevumi, pie kuriem ir pieskaitāmas lūgšanas, lai saņemtu Dieva mīlestību. Lai attīrītu savu dvēseli no grēkiem, māsām regulāri, katru sestdienu un pirms svētkiem, bija jāiet uz grēksūdzi. Tāpat svētdienās un visos baznīcas svētkos žēlsirdīgajām māsām bija jāiet pie Svētās komūnijas. Savukārt māsām bija aizliegts iestāties jebkurā brālībā (relig̣iskā organizācijā) bez apvienības priekšniecības atḷaujas. Lai novērstu dažādus pārkāpumus, kuri varēja ienest domstarpības žēlsirdīgo māsu vidū, māsām tika dota iespēja izrunāties visu priekšā. Katru piektdienu (izņemot Lielo Piektdienu pirms Lieldienām, un tās piektdienas, kad ir baznīcas svētki) pusastoņos vakarā pēc lūgšanām māsām bija jāierodas uz sapulci. Sanākšanu organizēja vecākā māsa, lai māsas varētu atzīt un izlabot savas kḷūdas un pārkāpumus atbilstīgi izstrādātajiem noteikumiem (Regulai). Šajā laikā katrai māsai bija jāatz̄ist sava vaina citu klātbūtnē un ar prieku jāpieņem aizrādījumi, kā arī jānožēlo grēki. Visi citu māsu pamanītie pārkāpumi, par kuriem viņas paziņoja, bija jāpieņem ar pateicību un ar vēlmi laboties, neizrādot naidu pret tām, kas konstatēja noteikumu neievērošanu. Tajā pašā laikā māsām bija aizliegts izpaust informāciju par notikumiem sapulcē.

Vecākā māsa bija jāinformē arī par citu māsu piel̦autiem nopietniem pārkāpumiem. Tajā pašā laikā katrai bija jāpriecājas, ka par visiem noteikumu neievērošanas gadījumiem tika informēta priekšniecība. 
Savukārt arī vecākās māsas nevarēja izvairīties no pārkāpumu atklāšanas, jo katrai māsai ar pazemību un mīlestību obligāti apvienības priekšniecībai bija jāpaziņo par ievērotajām kḷūdām vecākās māsas darbībā.

Kāda dienas kārtība bija jāievēro māsām, ir aprakstīts nodaḷā "Par dienas kārtību”. Māsām bija jācelıas pulksten četros no rīta, pēc zvana, un no paša rīta savas pirmās domas bija jāvelta Dievam. Puspiecos visām māsām kopā bija jālasa lūgšanas līdz pulksten sešiem. Pēc tam māsas varēja nodarboties ar savām neatliekamajām darīšanām. Vēlāk, pulksten septiņos, visām māsām bija jāiet uz dievkalpojumu.

Pēc dievkalpojuma visām kopā bija jābrokasto, ievērojot klusumu. Tās māsas, kuras nevarēja apmeklēt dievkalpojumu, ēda brokastis pirms Svētās Mises. Pēc pulksten 9.30 bez vecākās māsas atḷaujas brokastot bija aizliegts. Pēc brokastīm māsām bija jāatgriežas pie sava darba.

Pulksten 11.30 māsām bija jādomā par savām kḷūdām un izdarītiem grēkiem. Pēc tam viņām bija jālasa lūgšana Benedycte. Pēc lūgšanas māsas ēda pusdienas (katrai bija sava porcija). Pusdienu laikā māsām uzmanīgi bija jāklausās svētā lasīšana (lasīja viena no māsām). Lasīšana bija jāpabeidz ar lūgšanu Mavtyvologium un Angelus Domini. Pēc zvana, pat ja māsas nepabeidza pusdienot, bija jāaiziet no galda un jālasa lūgšana Benedycte.

Pēc pusdienām katrai bija jāveic savs darbs. Nodarbes laikā (piemēram, šūšanas) māsām bija atļauts runāt, bet ik pa brīdim viñām bija jāatceras, ka ir jāpacel̦ savas rokas Dieva slavēšanai. Gadījumā, ja sarunas laikā māsas pārkāpa kautrības robežas, vienai no māsām, kura būs tam nozīmēta, jāsaka: "Atcerieties par Dieva klātbūtni."

Pulksten 14.00 māsām bija jālasa lūgšana Veni Sancte Spiritus, pēc tam vienai no māsām skaļi jālasa vēl viena lūgšana pusstundas garumā. Svēto rakstu lasīšanu māsām bija jāpabeidz ar vārdiem: "Deus cavitas est, gui mavet in chavitate, in Deo manet et Deus in co." Pārējām māsām tas bija jāklausās dziḷā klusumā līdz pulksten 15.00. Tad viņas metās ceḷos, māsām bija jālasa trīs lūgšanas. Tām māsām, kuras šajā laikā atradās ārpus kopienas mājas, bija jālūdzas, nestājoties uz cel̦iem. Bet māsām, kuras kopā ar pārējām nevarēja veikt šo procedūru, tā bija jāizdara tuvākajā laikā.

Pēc tupēšanas uz celiem, ja māsas atradās kopā, vin̄ām tika atlauts parunāt sava starpā. Pulksten 18.00 bija jālasa lūgšana, tāpat kā pirms pusdienām, jāpārdomā par savām kḷūdām un grēkiem. Pēc tam - jāiet 
uz vakariņām, lasot lūgšanu Benedycte, pēc vakariṇām māsām vairākas reizes bija jāskaita rožukronis.

Pēc vakariṇām māsām bija jāveic arī tie darbi, kuri iekḷauti viṇu pienākumos. Gadījumā, ja nekas nebija jādara, tad visām bija jāšuj vai jāvērpj. Pulksten 20.15, pēc zvana, māsām bija jāpulcējas kopā lasīt lūgšanu. Kad vecākā māsa izlasīja lūgšanu Veni Sancte, māsām vajadzēja pārdomāt savas kḷūdas un grēkus, kurus viṇas bija piẹ̦āvušas dienas laikā, un vin̄ām bija jālasa svētie raksti.

Sestdienās un pirms baznīcas svētkiem māsām, stāvot uz ceḷgaliem, bija jālasa evaņgélijs. Pēc lūgšanas vajadzēja atgriezties pie sava darba. Pulksten 21.00 māsas devās gulēt. Svētdienās un svētkos žēlsirdīgajām māsām bija jāievēro tāda pati dienas kārtība kā citās dienās, bet ar dažiem izṇēmumiem. Laiku, kas paredzēts rokdarbiem darba dienās, bija jāpavada garīgai attīstībai veltītā darbībā. Viṇām bija jālasa arī svētās grāmatas, lai veiktu nabagu un bērnu izglītošanu par dvēseles glābšanu. Māsām, kurām tika atḷauts apgūt lasīšanas, rakstīšanas vai svešvalodu prasmes, šai nodarbei bija atvēlēts pusstundas laiks no rīta un tikpat daudz laika pēcpusdienā, lai nepārtrauktu kalpot nabagiem. Šajās dienās māsām bija paredzēta atpūta pēcpusdienā.

Visām māsām bija stingri jāievēro dienas kārtība, jo "tas viss Dieva dots". Ja kādai radās vēlme neievērot dienas režīmu, viņai bija jācenšas vēlmi pārvarēt. Savas ciešanas māsām bija jāpieņem, atceroties Jēzus Kristus vārdus, ka debesis būs pieejams tikai tiem, kuri cieš.

Regulas nodaḷā "Par slimnīcām un pakalpojumiem nabagiem un slimiem" bija noteikts žēlsirdīgo māsu darba uzdevums slimnīcās: Kunga Jēzus Kristus slavēšana un viņa goda celšana, jo viņš ir tēvs nabagiem un slimiem; kā arī sevis veltīšana slimo un ubagu kopšanai, pievēršot uzmanību kā dvēselei, tā arī ķermenim. Kas attiecas uz dvēseli, māsas pienākums bija mācīt slimus un nabagus cilvēkus par jautājumiem, kurus nepieciešamas zināt grēku izpirkšanai, sagatavojot viņus mūžīgai grēku sūdzēšanai. Runājot par cilvēka ķermeni, māsas nodrošināja slimniekus ar ēdienu, zālēm un apmierināja citas vajadzības slimības un vājuma laikā.

Nodaḷā "Par vecākās māsas pienākumiem slimnīcā” aprakstīti vecākās māsas pienākumi un nostādnes: vecākajai māsai vienmēr jātur priekšā savas apvienības noteikumi, lai viṇa būtu piemērs citām savām 
māsām; dodot rīkojumus citiem, pirmajai jādara visu, kas ir nepieciešams izmazgāt slimnieku traukus, sakārtot gultas, izslaucīt palātas. ${ }^{52}$

Veicot bērnu audzināšanu kristietības garā, māsām bija jāievēro Regulas papildu noteikumi. Bāreņu un nabago apmācība un audzināšana tika iekḷauta žēlsirdības māsu apvienības pienākumos, tāpat kā nabadzīgo un slimo kopšana. Tieši vecākajai māsai bija jāseko visai bāreņu audzināšanas un apmācības darbībai un notikumiem. Viņai palīdzēja kāda no māsām meistarēm vai citas māsas. Vecākajai māsai regulāri bija jāapmeklē bāreņu palātas, bija jābūt informētai par katra bāreņa paradumiem un uzvedību. Bez vecākās māsas aț̣aujas bija aizliegts apciemot bāreņus.

Galvenais māsu uzdevums bija jau no mazotnes iemācīt bērniem dievbij̄̄îu. Māsām bija jāmāca bērniem novērst pārkāpumus, jānoskaņo audzēkņi godīgumam un kārtībai. Meitenēm vairāk bija jāieaudzina kautrīgums, bet zēniem - godīgums. Bija aizliegts atstāt bērnus bez uzraudzības. Naktīs meiteņu telpās vajadzēja gulēt vienai vai divām sievietēm, un žēlsirdīgām māsām bieži bija jāveic apgaita un jāapskata, kā meitenes guḷ. Pie zēniem naktī vienmēr klāt atradās skolas direktors, lai viņus pieskatītu. Stingri bija aizliegts vienā gultā guldīt divus bērnus, izņemot pavisam mazos vai zīdaiņus. Kā meiteņu, tā arī zēnu istabās naktīs obligāti bija jādeg gaismai.

Māsas rūpīgi sekoja, lai bērni staigātu tīrās drēbēs un saglabātu kārtību savās istabās. Bērnus, kuri pārkāpa noteikumus, māsas brīdināja un noteica sodu. Dienas kārtībai bija jābūt sastādītai atsevišķ meitenēm un zēniem. Māsām stingri bija jāievēro arī dokumentācijas kārtošana. Skolās bija divi saraksti - atsevišş̧i zēniem un meitenēm. Tajos ierakstīja katra bērna vārdu, uzvārdu, vecumu, ziņas par vecākiem, iestāšanās skolā laiku. Bērna nāves gadījumā sarakstā māsas atzīmēja, kad un kur mirušais apglabāts.

Māsām, audzinot bērnus, bija īpaša uzmanība jāpievērš, lai bagāto ǵimeņu meitenes neatstumtu un nepazemotu bērnus no nabadzīgām ǵimenēm un bāreņus. Māsām meistarēm, kā arī citām darbiniecēm, bija jāklausa vecākā māsa, precīzi jāpilda viņas rīkojumi un uzdevumi. Citām māsām un darbiniecēm bija jāizrāda gods, paklausība un cieņa māsai meistarei. Māsām vajadzēja censties bērnu klātbūtnē nestrīdēties, nerunāt ko sliktu un citai par citu, neaprunāt. Skolā strādājošām māsām stingri bija jāievēro dienas

52 Lietuvos Valstybes istorijos archyvas, 604. f., 1. apr., 11720. b., 147.-160. 
kārtība, nekādā gadījumā nedrīkstēja mainīt to bez vecākās māsas atlaujas. Bija jāseko, lai bērni rūpīgi izpildītu visus praktiskos un garīgos pienākumus. Visus bērnus bija vienādi jāmīl - nedrīkstēja izrādīt simpātijas kādam bērnam vairāk. Ja gadījumā māsa pamanīja bērna sliktu uzvedību, viņa pārkāpēju brīdināja: pirmo reizi personiski, otro reizi - publiski. Bija aizliegts kliegt uz bērniem un lietot aizvainojošus vārdus. Ja kāds bērns nopelnīja sodu, māsai meistarei bija ațauts uzlikt sodu vai grēku nožēlošanu, bet iepriekš saskaņojot to ar savām darbiniecēm. Lielāko sodu un nožēlošanu bija tiesīga uzlikt vecākā māsa. Māsām rūpīgi bija jāseko, lai bērnu starpā tiktu stingri ievērota kārtība, vienotība un godīgums, bet jāuzmana, lai nebūtu draudzības un tuvības. Bija jāseko, lai bērni neveidotu mazas grupiņas un lai nebūtu aprunāšanas. Ar savu piemēru māsām bija jāparāda un jāmāca bērniem labdarība un paklausība. Viņām vajadzēja būt uzman̄̄gām, lai ne ar vienu sliktu vārdu un soli nerādītu bērniem nevēlamu piemēru. ${ }^{53}$

\section{Kopsavilkums}

Žēlsirdīgo māsu apvienības nodibināšana bija viens no soḷiem māsu profesijāa, lai viņas izietu no klosteru ēnas. Žēlsirdīgās māsas atradās baznīcas pakḷautībā. Viņas dzīvoja saskaņā ar mūķeņu apvienības garīgo dzīvesveidu, kas nedaudz atšķīrās, piemēram, viens no māsu pienākumiem bija slimo apraudz̄̄̌sana mājās. Š̄i darbība nesakrita ar klostera dzīves principiem, un žēlsirdīgās māsas bija vairāk pakḷautas grēkam nekā mūksenes, kuras dzīvoja klosteros.

Māsas darbs tika balstīts uz žēlsirdību, jo kalpot slimiem un ubagiem, kā arī audzināt un izglītot bērnus, nozīmēja kalpot Dievam. Piln̄̄ga sevis veltīšana Dievam tika īstenota, kalpojot nabagiem.

Māsu darbība un uzvedība bija stingri pakḷauta izstrādātajiem noteikumiem (Regulai). Balstoties uz Regulu, māsas tika audzinātas kristietības, labdarības, paklausības un pakḷautības garā. Par vienu no svarīgākajiem māsu pienākumiem uzskatāma tikumīga dz̄̄ve, apvienojot garīgos uzdevumus ar kristīgas mīlestības izpausmēm pret nabagiem. Māsām pienācās dzīvot dievbijīgu dzīvi un saglabāt gara koncentrāciju, ķermeņa

${ }^{53}$ Lietuvos Valstybes istorijos archyvas, 604. f., 1. apr., 11720. b., 160.-162. v. 
tīrību un domāšanas kontroli, lai viņas spētu atrauties no laicīgas dz̄ives un pilnīgi veltīt sevi kalpošanai nabagiem un slimiem. Regula noteica žēlsirdīgo māsu darbības galvenos virzienus: slimnieku kopšanu un bērnu izglītošanu.

Žēlsirdīgās māsas, atbalstot nemierniekus un piedaloties poḷu sacelšanās kustībā 1863. gadā, pārkāpa savas darbības noteikumus, tāpēc tika izsūtītas no Krāslavas.

Vincenta de Paula žēlsirdīgo māsu apvienības darbība lika pamatu māsu profesijas tālākai attīstībai un māsu garīgai audzināšanai, kura ir aktuāla arī mūsdienās. Viens no noteicošajiem faktoriem māsu labdarībā bija garīgā audzināšana un tās attīstīšana, saglabājot dvēseliskumu ne tikai savstarpējās attiecībās, bet arī ienesot to slimnieku kopšanā un bērnu audzināšanā. Šis faktors ir aktuāls arī mūsdienu praksē gan slimnieku aprūpē, gan izglītošanas jomā.

\section{Spiritual Upbringing of Vincent á Paulo's Sisters of Mercy Society}

\section{Abstract}

Vincent á Paulo's Sisters of Mercy society was founded in 1633 in Francewith the aim to provide help for the poor and the sick, to bring up and educate children in the spirit of Christianity. Sisters of Mercy needed spiritual education to perform this charitable task. To achieve the aim, the behaviour and working regulations (Regula) for nurses were worked out to be strictly observed. The work of Sisters of Mercy, which was based on mercy, received general support and respect from the community. These efforts gained popularity and recognition not only in France but also in other countries, having spread in the territory of Latvia as well. The mission of Vincent á Paulo's Sisters of Mercy society was continuing in the territory of Latvia (the town of Kraslava) for 75 years (from 1789 to 1864). Despite the country where merciful sisters worked, they had to observe the regulations, which were translated in different languages.

The foundation of Sisters of Mercy society was one of the steps in the nursing profession having left the traces of monasterys. The Sisters of Mercy, obeying the ecclesiastical authority, lived the spiritual way of 
life, absolutely unknown for society of nuns. So, one of the nursing duties was to visit the sick at home. This activity did not follow the principles of the monastic life, so Sisters of Mercy were more exposed to the opportunity of sin than nuns who lived in monasteries. The sisters' work, based on compassion, such as serving the sick and beggars, as well as bringing up and educating children, meant serving God. The complete self-consecration to God was implemented in serving the poor. Nursing activities and behaviors were strictly conformed with the regulations (Regula). Based on the regulations, the sisters were brought up in the spirit of Christianity, charity, obedience and submission. The virtuous life, combining the spiritual tasks with the Christian's expressions of love to the poor, was considered to be one of the major responsibilities of nurses. Nurses were due to live religiously and keep the spirit of strength, the purity of the body and mindcontrol to be able to escape secular life and devote themselves completely to serve the sick and the poor. Regula determined the main field of activities of the Sisters of Mercy: patient care and education.

Olga Fokina, Dr. med., docente

Rīgas Stradiṇa universitāte

olga.fokina@rsu.lv

Inga Millere, Dr. med., asoc. profesore

Rīgas Stradiṇa universitāte

inga.millere@rsu.lv 